\title{
The Relationship between Headteachers' Distributed Leadership Practices and Teachers' Motivation in National Primary Schools
}

\author{
Jamallulail Abdul Wahab ${ }^{1}$, Aida Hanim A. Hamid ${ }^{1}$, Surayati Zainal ${ }^{1} \&$ Md Fuad Md Rafik $^{1}$ \\ ${ }^{1}$ Universiti Kebangsaan Malaysia, Selangor, Malaysia \\ Correspondence: Jamallulail Abdul Wahab, Faculty of Education, Universiti Kebangsaan Malaysia, 43600 UKM \\ Bangi, Selangor, Malaysia. Tel: 60-3-8921-6288. E-mail: jamall64@ukm.my
}

\author{
Received: August 16, 2013 Accepted: October 14, 2013 Online Published: November 28, 2013 \\ doi:10.5539/ass.v9n16p161 URL: http://dx.doi.org/10.5539/ass.v9n16p161
}

\begin{abstract}
The distributed leadership approach have been practiced in most developing countries approximately more than centuries ago as an alternative to school leadership in effort to increase the student outcomes. This article aims to report and discusses findings of a study on identifying the level of distributed leadership practices among headteachers and the level of teachers' motivation in primary schools in Malaysia and the relationship between these variables. The respondents were 243 teachers from 12 national primary schools in Port Klang, Klang, Selangor. Random sampling technique was used to ensure that each element in the population stood a fair chance to be selected as samplings. This is a quantitative study using questionnaires as research instrument. A descriptive analysis (mean and percentage) was used to identify the level of distributed leadership among headteachers. A Pearson Linear Correlation Test was used to determine the relationships between four dimensions in the independent variable components (distributed leadership practices) and dependent variable (motivation). The research findings showed that the overall mean score for the level of distributed leadership among headteachers was high (mean $=3.94 ; \mathrm{SD}=0.484)$. While the overall mean score for the motivation level of teachers was moderate (mean $=3.11 ; \mathrm{SD}=0.562$ ). The research findings also showed that there was no significant relationship between headteachers leadership (correlation coefficient value $r=0.279$ ) and teachers motivation. The implications of the research findings on leadership and teachers motivation were further discussed.
\end{abstract}

Keywords: distributed leadership, headteacher, motivation, teacher, national primary school (SRK)

\section{Introduction}

Distributed leadership is a leadership practice which involves leadership sharing throughout the organisation in which the leadership responsibilities are shared within those with related skills and expertise. (Spillane et al., 2004). In schools namely, distributed leadership is meant for headteachers so that they are no longer carrying full responsibilities as school leaders (one-man-show) but rather giving focus on how to produce one work mechanism with shared accountabilities and shared learning culture. Distributed leadership refers to a system on collection of interactions between components which includes the leader, followers and situation which needs to be understood together (Spillane, 2005).

Study by Silins and Mulford (2002) on the impacts of leadership on student learning outcomes showed that students' achievement was progressing when the source of leadership was distributed throughout the school community and when teachers were given power related to issues which they perceived as important. Distributed leadership is based on the concept of school as one community of students and recognition towards headteacher or principal who are not able to lead alone (Hallinger, 2007). A strong learning community is developed when a headteacher learns to let go the controlling steps and assists the teachers to take part in developing the leadership throughout the school (McLaughlin \& Talbert, 2006). According to Harris, (2008), the distributed leadership theory has identified many capable and potential leaders in an organisation. When leadership is distributed widely and closed to learning site, it has huge influence on schools and students (Day et al., 2007). Eilis Humphreys (2010) has explored on the distributed leadership concept and the impact of distributed leadership on teachers teaching and learning. She found that distributed leadership has positive influence on teachers teaching and learning. 
Excellent leadership practices among headteachers are needed in national schools administration. In leading the national primary schools, headteachers are not only responsible towards school management but also teachers and students. The effectiveness of schools depends on the level of leadership approach practised by headteachers (Mohammed Sani \& Jamalullail, 2012). The leadership approach discussed in this article is distributed leadership. The policy of Malaysia Education Quality Standard (KPM, 2010) stated that parents were frequently questioning the quality of education received by their children in schools which giving the message that they no longer have the confidence on the ability of the schools to educate their children especially on the attitude of students after schools which are not up to the expectation of society and the country (UPE, 2010). According to Humphreys (2010), the practices of leadership among headteachers are able to deliver huge impact on the level of work performance among teachers because good leadership is well-accepted by the subordinates. This scenario is related to the leadership practices of administrators and level of motivation among teachers.

Some teachers do not like to get involved in decision-making process because most teachers are not motivated and they do not prefer to spend time in attending the school meetings. Teachers prefer to teach as compared to getting involved and committed to decision-making. This has to do with the implementation of limited empowerment process at school level (Abd Ghani, 2009). At school level, the involvement of teachers in decision-making process is an important issue. In distributed leadership practice, not everyone makes decision but everyone has the expertise and knowledge which contributes to the decision-making process. The distributed leadership practised by the headteachers could orientate the teachers to change the values and attitudes towards commitment of educational mission and vision (Sadariah, 2001). In addition, teachers have the opportunity to enhance and increase their leadership ability in preparing themselves to become future quality school leaders (KPM, 2013).

\section{Research Objective}

The objectives of this research are as follows:

1) To identify the level of distributed leadership practices among headteachers in national primary schools in Port Klang Zone, Selangor

2) To identify the level of motivation among teachers in national primary schools in Port Klang Zone, Selangor

3) To determine the relationship between the distributed leadership practices among headteachers and teachers' motivation in national primary schools in Port Klang Zone, Selangor.

\section{Methodology}

\subsection{Research Design}

This is a quantitative research and it uses survey approach in which questionnaires is used as research instrument. This study has two variables: independent variable and dependent variable. The dependent variable measured in this study is the level of motivation of teachers in national primary schools. Meanwhile the independent variable is the level of distributed leadership practices among headteachers in national primary schools. The analysis of the conducted pilot test showed that the instrument has high reliability (Cronbach's Alpha of 0.84 to 0.94 ).

\subsection{Sampling and Research Site}

Table 1 showed that the research respondents were 243 teachers from 12 national primary schools in Port Klang Zone, Klang, Selangor. The random sampling technique is used to ensure that every element in the population stand a fair chance to be selected as samplings. 
Table 1. Distribution of respondents and national primary schools (SRK)

\begin{tabular}{lcccc}
\hline No & School Code & No. of teachers & No. of samplings & Percentage (\%) \\
\hline $\mathbf{1}$ & SRK 1 & 72 & 25 & 35 \\
$\mathbf{2}$ & SRK 2 & 51 & 18 & 35 \\
$\mathbf{3}$ & SRK 3 & 63 & 22 & 35 \\
$\mathbf{4}$ & SRK 4 & 69 & 24 & 35 \\
$\mathbf{5}$ & SRK 5 & 96 & 34 & 35 \\
$\mathbf{6}$ & SRK 6 & 76 & 27 & 35 \\
$\mathbf{7}$ & SRK 7 & 70 & 25 & 35 \\
$\mathbf{8}$ & SRK 8 & 41 & 14 & 35 \\
$\mathbf{9}$ & SRK 9 & 58 & 20 & 35 \\
$\mathbf{1 0}$ & SRK 10 & 34 & 12 & 35 \\
$\mathbf{1 1}$ & SRK 11 & 31 & 11 & 35 \\
$\mathbf{1 2}$ & SRK 12 & 29 & 10 & 35 \\
& & $\mathbf{6 9 0}$ & $\mathbf{2 4 3}$ & \\
\hline
\end{tabular}

\subsection{Research Instrument}

The research instrument used in this study is a set of questionnaires which comprises of three parts: A, B and C. Part A is questions on the background of respondents. To identify the level of distributed leadership, an instrument developed by Connecticut State Department of Education (CSDE) is adapted in Part B. The instrument is known as Distributed Leadership Readiness Scale (DLRS). In part C, 38 questions are used to measure the level of motivation by using the instrument known as Questionnaire Measure of Individual Differences in Achieving Tendency (QMAT). Each item is measured by using Likert Scale 1- Totally Disagree, 2-Disagree, 3-Neutral, 4-Agree dan 5-Totally Agree.

\subsection{Data Analysis}

Descriptive analysis is used to identify the level of distributed leadership among headteachers (mean and standard deviation). The level of distributed leadership among headteachers in the schools of Port Klang Zone comprises of four distributed leadership: set and shared mission, vision and school goals, school culture, shared responsibilities and leadership practices. Meanwhile a linear Pearson correlation test is used to determine the relationship between four dimensions of the independent variable component (distributed leadership practices) and dependent variable (motivation). The obtained data is recorded and processed by using Statistical Package for the Social Sciences (SPSS) version 18.0.

\section{Research Findings and Discussion}

\subsection{Level of Distributed Leadership Practices among Headteachers}

Table 2. Mean value of level of distributed leadership among headteachers

\begin{tabular}{llc}
\hline & \multicolumn{1}{c}{ Construct/ Dimension of Distributed Leadership } & Mean \\
\hline 1. & Set and shared mission, vision and school goals & 3.82 \\
2. & School culture & 4.04 \\
3. & Shared responsibilities & 3.93 \\
4. & Leadership practices & 3.61 \\
& Overall mean average & 3.85 \\
\hline
\end{tabular}

Table 2 showed the overall mean average value of the level of distributed leadership among headteachers is 3.85 . Based on Table 3, $t$ the level of distributed leadership is high. The findings obviously showed that the distributed leadership practices among headteachers in national primary schools in Port Klang Zone are at high level. All 
four dimensions of distributed leadership measured showed high level of practices (mean=3.82, 4.04, 3.93), except for dimension of 'Leadership practice' which at moderate level (mean=3.61). These research findings are supported by Rosnarizah (2008) who stated that the average mean for all four dimensions in her study indicated that $73.59 \%$ respondents agreed that distributed leadership was practised in schools and the score of the existence of distributed leadership in national primary schools in Port Klang Zone is high. These results also supported the distributed leadership theory by Alma Harris (2008) who identified that many are capable and potential in becoming leaders in the organisation. Nevertheless, Harris further stressed that the key success of distributed leadership relies on how leadership is made easier and given support in improving the education quality.

Table 3. Interpretation of level of distributed leadership among headteachers

\begin{tabular}{ll}
\hline Level of Distributed Leadership among headteachers & Range of Mean Score \\
\hline Low & $1.00-2.33$ \\
Moderate & $2.36-3.66$ \\
High & $3.67-5.00$ \\
\hline
\end{tabular}

Source: Harris (2008) in Rosnarizah (2008)

\subsection{Level of Work Motivation among Teachers in National Primary Schools in Port Klang Zone, Selangor}

Level of work motivation among headteachers in national primary schools is shown in Table 4.

Table 4. Mean and standard deviation of the level of motivation among teachers in national primary schools in Port Klang Zone

\begin{tabular}{|c|c|c|c|}
\hline No. & Statement & Mean & $\begin{array}{l}\text { Standard } \\
\text { Deviation }\end{array}$ \\
\hline 1. & I normally complete my planned work. & 3.07 & .792 \\
\hline 2. & It is difficult for me to work in a new and unfamiliar situation. & 3.26 & .441 \\
\hline 3. & I am optimistic in my work matters. & 3.09 & .810 \\
\hline 4. & I rarely accept work that others find difficult & 2.99 & .747 \\
\hline 5. & I am unsure to make important decision at work. & 3.28 & .450 \\
\hline 6. & The idea that I need to work hard for promotion never crosses my mind. & 3.12 & .488 \\
\hline 7. & $\begin{array}{l}\text { I give priority to work which is important, difficult and has } 50 \% \text { possibility of } \\
\text { failure as compared to work which is important but easy. }\end{array}$ & 2.88 & .795 \\
\hline 8. & I am attracted to take more responsibility than actual needed. & 2.91 & .282 \\
\hline 9. & I am disturbed when I think of things related to new work. & 3.56 & .648 \\
\hline 10. & I am satisfied to accomplish important work which needs extra efforts. & 2.80 & .399 \\
\hline 11. & I cannot work properly when I am under pressure. & 2.72 & .450 \\
\hline 12. & I believe that if I work hard, I will achieve my life goals. & 3.45 & .498 \\
\hline 13. & I am proud of my work. & 2.89 & .916 \\
\hline 14. & Learning new skills does not excite me. & 3.13 & .646 \\
\hline 15. & I only work hard as what is expected. & 3.45 & .498 \\
\hline 16. & I am keen to set tough goal for myself. & 3.19 & .575 \\
\hline 17. & I love doing easy task after learning it. & 2.67 & .649 \\
\hline 18. & I have high ambition. & 3.20 & .399 \\
\hline 19. & I give priority to daily small project than long term project. & 3.58 & .613 \\
\hline 20. & I really like task that requires efforts to overcome the obstacles. & 3.00 & .000 \\
\hline
\end{tabular}


21. I appreciate the opportunity that enables me to know my strengths and weaknesses.

22. I only get little satisfaction when I work hard.

23. Nowadays, I find that there is less promotion unless one is given the opportunity.

24. Solving simple problem does not give me satisfaction as compared to how I have done in tough work.

25. I give priority to work that requires my personal thinking.

26. I love works that require my personal thinking.

27. I work because I have to.

28. I frequently succeed to accomplish the important goals that I have set.

29. I am relief but I am not satisfied when I complete difficult work.

30. I am able to deliver good job when I work in competition environment.

31. Continuous work to achieve goals is not rewarding in my life.

32. I always try to do difficult job which I am not sure whether I could do it than trying a job that is easy which I believe I could do it.

33. I am not satisfied until I have not reached excellence.

34. I do not like to be responsible for handling tough situation.

35. I give priority to challenging jobs.

36. When I do a job, I set a high degree performance without considering how the others do it.

37. I always predict and avoid from a situation which failure possibility is moderate.

38. I prefer to work which I feel confident and easy than doing work which is tough and challenging.

Table 4 shows that the value of overall average mean of the level of motivation among teachers towards work (tasks) in national primary schools in the district of Klang is $3.11(\mathrm{SD}=.562)$. Based on table 5 , the mean value is 3.11 which are at high level.

Table 5. Interpretation of the mean score of the level of teachers' motivations

\begin{tabular}{lcc}
\hline No. & Level & Mean Score \\
\hline 1. & Very Low & $1.00-2.00$ \\
2. & Low & $2.01-3.00$ \\
3. & High & $3.01-4.00$ \\
4. & Very High & $4.01-5.00$ \\
\hline
\end{tabular}

Source: Mehrabian and Bank (1978) in Yaacob (1995)

The research findings shows that the mean score for the level of motivation among teachers towards work is at high level with mean value $=3.11(\mathrm{DP}=.562)$. The overall mean score is at high level.

\subsection{The Relationship between Distributed Leadership among Headteachers and Motivation among Teachers}

Table 6 shows that there is a significant relationship between the distributed leadership practices and the level of motivation among teachers in national primary schools in Port Klang Zone. However, the relationship is weak ( $\mathrm{r}$ 
$=0.279, \mathrm{p}<0.05)$.

Table 6. The relationship of distributed leadership among headteachers and the level of motivation among teachers

\begin{tabular}{|c|c|c|c|c|}
\hline & & & $\begin{array}{c}\text { Score Percentage of } \\
\text { Motivation }\end{array}$ & $\begin{array}{l}\text { Percentage Score of } \\
\text { Distributed Leadership }\end{array}$ \\
\hline \multirow{3}{*}{$\begin{array}{l}\text { Score Percentage } \\
\text { Motivation }\end{array}$} & \multirow{3}{*}{ of } & Significant & 1 & $0.279^{*}$ \\
\hline & & Correlation (2-tailed) & & 0.000 \\
\hline & & $\mathrm{N}$ & 243 & 243 \\
\hline \multirow{3}{*}{$\begin{array}{l}\text { Score Percentage } \\
\text { Distributed leadership }\end{array}$} & \multirow{3}{*}{ of } & Significant & 0.279 & 1 \\
\hline & & Correlation (2-tailed) & 0.000 & \\
\hline & & $\mathrm{N}$ & 243 & 243 \\
\hline
\end{tabular}

* Correlation is significant at level $\alpha=0.01$ (2-tailed)

These findings are in line with Mohd Najib (2004) who stated that the leadership styles of principals in eight schools in the District of Kota Star, Kedah Darul Aman has weak relationship with teachers' motivation. Yusuf (2004) in his study on Leadership Styles of Head of Office and its Relationship with Staffs Motivation found that there was significant relationship between leadership styles of directors and motivation of subordinates. Meanwhile, Ori Eyal and Guy Roth (2011), in their study entitled "Principals' leadership and teachers' motivation: Self-determination theory analysis", suggested that leadership styles among headteachers play important roles in motivating teachers and their well-beings. Harris (2008) highlighted potential for distributed leadership to make a difference in organisational change and great improvement is through motivation and teachers professional development.

\section{Research Implications}

Although the research findings showed that the overall level of distributed leadership practices among headteachers in national primary schools in Port Klang Zone, Selangor was high, there was one dimension that are at moderate level, which was leadership practices. Hence, the distributed leadership practices among headteachers need to be improved. Similarly, the level of motivation among teachers in national primary schools in Port Klang Zone, Selangor was overall at high level. However, the relationship aspect of this research showed that there was a relationship between the distributed leadership practices among headteachers and motivation among teachers but the relationship was weak. The distributed leadership practices should be implemented effectively as it has impact on the students learning outcomes (Silins \& Mulford, 2002).

Further, these research findings provide information to various agents especially to key stakeholders on the aspects of the relationship between distributed leadership and teachers' motivation. For the policymakers and implementers such as Malaysia Ministry Education, Selangor Education Office and Klang District Education Office namely, these research findings could assist them to plan and implement effective professional leadership programs which suit headteachers in Port Klang Zone. This could help on the delivery process and improvement of distributed leadership practices in schools of particular area. In addition, these research findings could inspire the teachers to reflect on their level of work quality and practices for further improvement.

Researches related to distributed leadership in Malaysia are still at initial stage. This scenario is common as distributed leadership among headteachers in Malaysia are still new, hence, further research need to be actively conducted in seeing to what extent this leadership approach could be utilised in optimum.

\section{References}

Ali, S. M. (2001). Perkaitan antara gaya, saluran dan keberkesanan komunikasi pengetua dengan motivasi guru. Latihan Ilmiah Sarjana Pendidikan. Universiti Kebangsaan Malaysia.

Day, C., Sammons, P., Harris, A., Hopkins, D., Leithwood, K., Gu, Q., ... Kington, A. (2007). The Impact of School Leadership on Pupil Outcomes. DCSF Interim Report (Year 1). London: Department for Children, Schools and Families.

Eyal, O., \& Roth, G. (2011). Principals' leadership and teachers' motivation: Self-determination theory analysis. 
Journal of Educational Administration, 49(3), 256-275. http://dx.doi.org/10.1108/09578231111129055

Ghafar, M. N. A. (2004). Amalan Kepimpinaan Pengajaran Pengetua Sekolah Menengah Luar Bandar. Serdang: UPM.

Halim, R. A., \& Manaf, Z. A. (2008). Kajian Eksplorasi Distributed Leadership di Malaysia.

Hallinger, P. (2007). Research on the Practice of Instructional and Transformational Leadership: Retrospect and Prospect. Australian Council For Educational Research. Mahidol University.

Harris, A. (2004). Distributed leadership and school improvement: Leading or misleading. Educational Management Administration \& Leadership. London: SAGE Publication.

Harris, A. (2008). Distributed leadership according to the evidence. Journal of Educational Administration. Distributed leadership through the looking glass, 46(2), 172-188.

Humphreys, E. (2010). Distributed Leadership and Its Impact on Teaching and Learning. Education Doctorate Thesis. Ireland: NUI Maynooth Education Department.

Ibrahim, M. S., \& Wahab, J. A. (2012). Kepimpinan Pendidikan. Bangi: Penerbitan Universiti Kebangsaan Malaysia.

Jaafar, A. G. (2009). Hubungan Antara Motivasi Guru Dengan Motivasi Dan Pencapaian Akademik Pelajar. Psikologi Pendidikan Universiti Teknologi Malaysia. No. perolehan: 9274.

Kementerian Pelajaran Malaysia. (2012). Pelan Pembangunan Pendidikan Malaysia 2013-2025. Putraajaya: KPM

McLaughlin, M. W., \& Talbert, J. E. (2006). Building school-based teacher learning communities: Professional strategies to improve student achievement. New York: Teachers College Press.

Mehrabian, A., \& Bank, L. (1978). A questionnaire measure of individual differences in achieving tendency. Educational and Psychological Measurement, 38, 475-478. http://dx.doi.org/10.1177/001316447803800234

Rofi, Y. M. (2004). Gaya Kepimpinan Ketua Pejabat dan Hubungannya dengan Motivasi Staf Bawahan: Kajian di Jabatan Penilaian dan Perkhidmatan Harta Negeri Terengganu, Kementerian Kewangan Malaysia. Tesis sarjana Universiti Utara Malaysia.

Silins, H., \& Mulford, B. (2002). Leadership and school results. In K. Leithwood, \& P. Hallinger (Eds.), Second International Handbook of Educational Leadership and Administration (pp. 561-612). Norwell, MA: Kluwer Academic Publishers. http://dx.doi.org/10.1007/978-94-010-0375-9_21

Spillane, J. P. (2005). Distributed Leadership. The Educational Forum, 69(2). http://dx.doi.org/10.1080/00131720508984678

Spillane, J. P., Halverson, R., \& Diamond, J. B. (2004). Towards a theory of leadership practice: A distributed perspective. Journal of Curriculum Studies, 36(1), 3-34. http://dx.doi.org/10.1080/0022027032000106726

Stogdill, R. M. (1978). Handbook of Leadership. New York: The Free Press.

Unit Perancang Ekonomi (EPU). (2010). Rancangan Malaysia Kesepuluh. Purajaya: Jabatan Perdana Menteri.

\section{Copyrights}

Copyright for this article is retained by the author(s), with first publication rights granted to the journal.

This is an open-access article distributed under the terms and conditions of the Creative Commons Attribution license (http://creativecommons.org/licenses/by/3.0/). 